\title{
Survey, Population Dynamics and Estimation of Damage of Common Land Snail Species on Some Vegetable Plants and Egyptian Clover at Some Regions at Kafr El-Sheikh Governorate Alyaa A.Gazzy ${ }^{1}$; Nadia M. Mostafa ${ }^{2}$ and Wafaa A. Shahawey ${ }^{2}$ ${ }^{1}$ Dept. of zoology, Faculty of Science Kafr El-Sheikh University. ${ }^{2}$ Plant Protection Research Institute, A.R.C, Egypt.
}

\begin{abstract}
Survey and population dynamics were carried out in two regions, Abu-Abdalla village, Sedi Salem District and Salait village, Quallen district at Kafr El- Sheikh Governorate during two successive seasons from 2015to2017 on egyptian clover, lettuce, and cabbage. The survey revealed the existence of four species of land snails, Monacha cantiana, Succinea putris, Theba pisana and Cochlicella acuta were predominant on egyptian clover and two vegetables crops. The population densities of these land snail species were studied on soil, stems and leaves of studied plants. The results showed that the highest population was recorded on leaves under field of vegetable plants during spring seasons except cabbage at Abu Abdalla, Sedi Salem district in 2015 and 2016. T.pisana presented in Lettuce and and Cabbage on Abu-Abdella village and was absent on all vegetable crops on the second village. while M. cantiana,C.acuta and S.putris snails were recorded with highest numbers on Egyptian clover. On the other hand, S. putris was in heavy infestation on lettuce and cabbage in the two regions. The damage caused by different snail species M. cantiana and S. putris was studied on Egyptian clover.
\end{abstract}

Keywords: land snails, Monacha cantiana, Theba pisana, Succinea putris and Cochlicella acuta.

\section{INTRODUCTION}

The land molluscs is one of the most important pests in all over world countries. These pests infest all growth stages of plants, so they caused yield reduction to vegetable, fruit crops and ornamental plants (Baur and Baur, 1993). They were known as destructive pests causing severe damage to vegetables and field crops that may be related to the secretion of the mucus and the particular structure of their mouth parts enabling scratching and crushing. (Ghamry et al.1993, Kassab and Daud. 1964, El-Deeb et al. 1996, Hegab et al. 1999 and Mahrous et al. 2002). It was evident that, they have medical and veterinary importance as they are intermediate hosts to some parasitic worms infecting human and domestic animals (Godan, 1983). The herbivorous land snail species which were recoeded on lettuce, cabbage and Egyptian clover. i.e. M. cantiana, $S$. putris, T. pisana and C. acuta which stated on vegetables and field crops at Kafr El-Sheikh Governorate. Ecological studies play an important role in determination their distribution and biology. So, the aim of present study was to detect the ecological factors that helps to design safety and successful control programs of these pests to avoid environmental chemical pollution, in addition to estimate the damage on three host plants i.e. Lettuce; cabbage,; and Egyptian clover, caused by these species

\section{MATERIALS AND METHODS}

\section{1- Survey studies:}

These studies of different land snail species were conducted under field conditions at Abu -Abdalla village, Sedi salem district and Salait village, Quallen district at Kafr El-Sheikh Governorate. In this respect, plantations of egyptian clover (Trifolium alexandrium) as a field crop, lettuce (Lactuca sativa) and cabbage (Brassica oleracea) as vegetable crops were chosen in these regions to estimate population density of different land snail species . monthly survey at period from September 2015 to August 2017during two successive seasons. In each district, one feddan from each plant species was randomly chosen, 5\% wetted bran baits were used as attractive bait and distributed beside and under plants before sun set as a land trap. The snails were collected and transported to laboratory in white close bags to identified according to Godan (1983).

2- Population dynamics of certain land soil species on certain crops:

Population density of $M$. cantiana, S. putris, $T$. pisana and $C$. acuta. were monthly recorded at each region from September 2015 to August 2017 on lettuce, cabbage and egyptian clover. Ten samples using the quadrate samples, each of $1 \mathrm{~m}^{2}$ were taken from one fadden as an experiment area and replicated three times in early morning.

3- Damage estimation of certain land snail species to Egyptian clover:

This experiment was carried out to estimate the damage caused by M. cantiana, C. acuta and S. putris on egyptian clover during February,2016. An area of $(3 \times 3 \mathrm{~m})$ cultivated with clover, $35-40 \mathrm{~cm}$ in length, they were reduced to plants similar in size divided into groups each of them 30 plant were randomly chosen, each group was caged with wire box ( $30 \mathrm{~cm}$ length $\times 30 \mathrm{~cm}$ wide $\times 50 \mathrm{~cm}$ high). Soil under cages were cleaned from weeds and grass, snails and new hatching to obtain free- snail plants. An artificial infestation was induced with four levels of adult M.cantiana, C. acuta and S.putris (i.e 10, 15, 20 and 25 individuals ) in addition to cage was used as a check control without snails . Each treatment was replicated 3 times. One month after infestation, fresh weight of shoots (first cut) was detected. This repeated two times after one month cutting. Reduction percentage of fresh weight were calculated using the formula:

Reduction \% = Average weight of control - Average weight of infested plants / Average weight of control

\section{RESULTS AND DISCUSSION}

These ecological studies are very important to help us in design successful programs to protect crops from damage caused by different land snails.

\section{Survey studies:}

Although terrestrial molluscs (slugs and snails) seem poorly suited by their biology to become pests, they frequently cause problems. Land snail species infested egyptian clover and vegetables at Abu-Abdalla village, Sedi salem district and Salait village, Quallen district at KafrEl- 
Sheikh Governorate were surveyed. The data in Table (1) could be presented according to Godan (1983) as the following:

Data in Table (1) revealed that the herbivorous land snail species belonging to families, Helicidae and Succinidae which were found on different plants. These species were $M$. cantiana, S. putris, T. pisana and C. acuta (Muller). These species varied in level of infestation according to each locality and host type. The snail, S. putris was recorded in all surveyed localities, with heavy infestation on the three crops in the two localities. Generally, the listed hosts can be classified into three categories according to the degree of infestation. These were; heavy, moderate and light infestation.

The majority of the examined crops were found with heavy infestation of the three species $M$ cantiana, S. putris and C. acuta on egyptain clover in the two localities. Cabbage was infested at range from heavy to moderate at Abu-Abdalla village, Sedi Salem district. Heavy infestation on Lettuce according to the high infestation of two species, $S$ putris and $T$ pisana in Abu-Abdalla village. The other species showed limited distribution, T. pisana was found on cabbage with moderate infestation in Abu-Abdalla village.

In Salait village, Quallen district, C. acuta was found with moderate infestation on cabbge and high infestation on egyptian clover fields . Heavy infestation with $S$. putris snails were found on egyptian clover and most of vegetables crops in all surveyed localities. Also, the data of the table (1) showed that absence of $T$. pisana snails in Salait village. $M$. cantiana snails were found with heavy infestation on all crops which surveyed especially egyptian clover which becomes problem to farmers and their animal. Ismail et al.(2011) found that Monacha cartusiana ( Muller) and S. putris snails at Hehia and Meniet El-Kamh. Also, they reported that $M$. cartusiana was found heavy infestation on the majority of examined crops and higher density than $S$. Putris on agricultural crops and weeds.

Table 1. Survey and distribution of land snail species at different localities of Kafr El- Sheikh Governorate .

\begin{tabular}{|c|c|c|}
\hline Location & Snail species & Host plant \\
\hline \multirow{8}{*}{ Abu-Abdalla village } & \multirow[t]{2}{*}{ Monacha cantiana } & Brassica oleracea \\
\hline & & Trifolium alexandrinum $(+++)$ \\
\hline & Cochlecilla acuta & Trifolium alexandrinum $(+++)$ \\
\hline & \multirow{3}{*}{ Succinea putris } & Brassica oleracea \\
\hline & & Lactuca sativa \\
\hline & & Trifolium alexandrinum $(+++)$ \\
\hline & \multirow{2}{*}{ Theba pisana } & Lactuca sativa \\
\hline & & Brassica oleracea \\
\hline \multirow{9}{*}{ Salait villag } & \multirow{3}{*}{ Monacha cantiana } & Trifolium alexandrinum(+++) \\
\hline & & Lactuca sativa \\
\hline & & Brassica oleracea \\
\hline & \multirow{2}{*}{ Cochlecilla acuta } & Brassica oleracea \\
\hline & & Trifolium alexandrinum $(+++)$ \\
\hline & \multirow{3}{*}{ Succinea putris } & Trifolium alexandrinum $(+++)$ \\
\hline & & Lactuca sativa \\
\hline & & Brassica oleracea \\
\hline & Theba pisana & None \\
\hline $\begin{array}{l}(++) \text { Heavy infestation } \\
(+) \text { Moderate infestation } \\
(+) \text { Light infestation }\end{array}$ & & \\
\hline
\end{tabular}

\section{2- Population dynamics:}

Data in Table (2) showed that, the tested crops were infected by all snail species and the population dynamics on lettuce, cabbage and Egyptian clover were recorded during the first season 2015-2016 at Abu Abdalla, Sedi Salem district. Results showed the total number of the snail T. pisana on lettuce recorded highest number 84.0 snail $/ \mathrm{m}^{2}$ followed by S.putris 68.9 snails $/ \mathrm{m}^{2}$. All snail species were found on lettuce from October 9.0, 5.3, 7.0 and 12.0 snail $/ \mathrm{m}^{2}$ for M. cantiana, S. putris, T. pisana and C. acuta. The infection continued to April to recorded 15.4, 14.0, 14.4 and 15.0 snails $/ \mathrm{m}^{2}$. Also, data in the same table showed the snails $M$. cantiana, S. putris and T. pisana were recorded on cabbage and infestation was started from September 14.0, 18.1 and 17.2 snail $/ \mathrm{m}^{2}$, respectively, then the population fluctuated to reach the maximum 15.3 , 18.1 and 19.9 in April ,September and October for $M$. cantiana, S. putris and T. pisana, respectively. The three species recorded the highest number during September 49.3 snail $/ \mathrm{m}^{2}$.

In the same table, results showed that the Egyptian clover was infected by three snail species from December to May. The number of $M$. cantiana was the highest number 415.2 snail $/ \mathrm{m}^{2}$ followed by C. acuta which recorded 264.0 snail $/ \mathrm{m}^{2}$ then $S$. putris recorded 132.0 snail $/ \mathrm{m}^{2}$. The total number of M. cantiana increased to reach 151.2 snails $/ \mathrm{m}^{2}$ during April, while $S$. putris recorded 44.0 during March and C. acuta 122.0 during April. Maha and Awad (2008) concluded that the highest figures of the population density of the tested snails, Succinea putris and Succinea elgans was observed during April and May due to the suitable climatic conditions of temperature and humidity during this period which confirm these results. Also, Ismail (1997) and El-Deeb et al. (1999) reported that the highest population density values of Monacha cartusiana (Muller) were found during spring months as compared with the other ones. Also, Abdel-Aal (2001) indicated that the population density of $M$. cartusiana increased during spring months. In addition to, Samy et al. (2015) recorded that the highest population densities were in March and April on lettuce, cabbage and onion plantations at El-Riad and Sidi- Salem district. 
Data in Table (3) showed that, M. cantiana, S. putris, T. pisana and C. acuta were recorded on lettuce and cabbage and Egyptian clover plants during all months of second season growth 2016- 2017 at Abu Abdalla, Sedi Salem district. C. acuta were found on lettuce and Egyptian clover only and absent in cabbage. The infection was beginning in October and December continued to end of growth season on lettuce and Egyptian clover, respectively. The snail species reached their peak during April on lettuce (76.0, 41.6, 39.0 and 16.4 snails $/ \mathrm{m}^{2}$ ) of M. Cantiana, S. Putris, T. pisana and C. acuta respectively. Ghamry et al., 1993; Arafa, 1997; Ismail, 1997; El-Masry, 1997; and Hegab et al. 1999 recorded that M. cartusiana, Eobania vermiculatsa, C.acuta and Helicella Vestalis in certain localities in Sharkia Governorate attacking field and vegetable crops, fruit trees and ornamental plants. Data obtained showed that in lettuce, the snail M. cantiana reached total numbers of counted snails were 188.4 during the whole season followed by $T$. pisana 127.0 snails $/ \mathrm{m}^{2}$ and S. putris was 108.9 snails $/ \mathrm{m}^{2}$ while $C$. acuta was the lowest number 43.0 snail $/ \mathrm{m}^{2}$. In cabbage, S.putris snails infested the plants during the growth season with total number 124.7 snails $/ \mathrm{m}^{2}$ followed by $T$. pisana 112 snails $/ \mathrm{m}^{2}$ and M. cantiana 49.1 snails $/ \mathrm{m}^{2}$. Peaks of T. pisana and S. putris were 32.0 and 31.0 snail $/ \mathrm{m}^{2}$, during March respectively, while $M$. cantiana recorded its peak during April 27.0 snails $/ \mathrm{m}^{2}$. In the same table data showed that M. cantiana, S. putris and C. acuta were found on clover from December,2016 until May,2017. The highest infestation was recorded by M. cantiana 616.0 snails $/ \mathrm{m}^{2}$ followed by $C$. acuta 273.0 snails $/ \mathrm{m}^{2}$ and $S$. putris 236.0 snails/ $\mathrm{m}^{2}$. The highest population density of these snails was recorded during April 273.0, 77.0 and 100.0 snails $/ \mathrm{m}^{2}$ for $M$. cantiana, $S$. putris and C. acuta, respectively. The minimum was 8.0 and 3.0 snails $/ \mathrm{m}^{2}$ for M. cantiana and $S$. putris during December 2016and 5.0 snails $/ \mathrm{m}^{2}$ for C. acuta during January,2017.

Table 2. Population dynamics of species on plants at Abu Abdalla, Sedi Salem district, Kafr El-Sheikh Governorate 2015- 2016 season.

\begin{tabular}{|c|c|c|c|c|c|c|c|c|c|c|c|c|c|}
\hline \multirow{3}{*}{$\mathbf{p}$} & \multicolumn{13}{|c|}{ Average number of snail species on different crops } \\
\hline & \multicolumn{5}{|c|}{ Lettuce } & \multicolumn{4}{|c|}{ Cabbage } & \multicolumn{4}{|c|}{ Egyptian clover } \\
\hline & $\mathbf{M}$ & $\mathbf{S}$ & $\mathbf{T}$ & $\mathbf{C}$ & Total & $\mathbf{M}$ & $\mathbf{S}$ & $\mathbf{T}$ & Total & $\mathbf{M}$ & $\mathbf{S}$ & $\mathbf{C}$ & Total \\
\hline Sep. & - & - & - & - & - & 14.0 & 18.1 & 17.2 & 49.3 & - & - & - & - \\
\hline Oct. & 9.0 & 5.3 & 7.0 & 12.0 & 33.3 & 13.0 & 16.0 & 19.9 & 48.9 & - & - & - & - \\
\hline Nov. & 7.0 & 10.0 & 14.4 & 7.5 & 38.9 & 10.9 & 12.0 & 16.4 & 39.3 & - & - & - & - \\
\hline Dec. & 5.0 & 12.0 & 8.0 & - & 25.0 & - & 18.0 & 19.0 & 37.0 & 21.0 & 18.0 & 9.0 & 48.0 \\
\hline Jan. & 9.0 & 9.4 & 10.0 & - & 28.4 & 13.7 & 17.4 & 11.0 & 42.1 & 34.0 & 19.0 & 17.0 & 70.0 \\
\hline Feb. & 9.5 & 7.2 & 13.0 & 6.0 & 35.7 & 12.0 & 13.0 & 13.0 & 38.0 & 65.0 & 23.0 & 23.0 & 111.0 \\
\hline Mar. & 13.0 & 11,0 & 17.2 & 11.0 & 52.2 & 10.0 & 17.0 & 17.0 & 44.0 & 132.0 & 44.0 & 93.0 & 269.0 \\
\hline Apr. & 15.4 & 14.0 & 14.4 & 15.0 & 58.8 & 15.3 & 12.0 & 12.0 & 39.3 & 151.2 & 28.0 & 122.0 & 301.2 \\
\hline May. & - & - & - & - & - & - & - & - & - & 12.0 & - & - & - \\
\hline Jun. & - & - & - & - & - & - & - & - & - & - & - & - & - \\
\hline Jul. & - & - & - & - & - & - & - & - & - & - & - & - & - \\
\hline Aug. & - & - & - & - & - & - & - & - & - & - & - & - & - \\
\hline Total & 67.9 & 68.9 & 84.0 & 51.5 & 272.3 & 88.9 & 123.5 & 125.5 & 337.9 & 415.2 & 132.0 & 264.0 & 811.2 \\
\hline Mean & 5.32 & 5.6 & 7.0 & 4.3 & 220.4 & 5.5 & 10.3 & 10.6 & 28.5 & 36.3 & 11.0 & 22.0 & 95.1 \\
\hline
\end{tabular}

Table 3. Population dynamics of snail species on different crops at Abu-Abdalla village, Sedi Salem district, Kafr ElSheikh Governorate during 2016-2017 season.

\begin{tabular}{|c|c|c|c|c|c|c|c|c|c|c|c|c|c|}
\hline \multirow{3}{*}{ Months } & \multicolumn{13}{|c|}{ Average number of snail species on different crops $/ \mathbf{m}^{2}$} \\
\hline & \multicolumn{5}{|c|}{ Lettuce } & \multicolumn{4}{|c|}{ Cabbage } & \multicolumn{4}{|c|}{ Egyptian clover } \\
\hline & $\mathbf{M}$ & $\mathbf{S}$ & $\mathbf{T}$ & $\mathbf{C}$ & Total & $\mathbf{M}$ & $\mathbf{S}$ & $\mathbf{T}$ & Total & $\mathbf{M}$ & $\mathbf{S}$ & $\mathbf{C}$ & Total \\
\hline Sept & - & - & - & - & - & 2.3 & 5.0 & 6.0 & 13.3 & - & - & - & - \\
\hline Oct & 4.2 & 4.1 & 9.0 & 2.6 & 19,9 & 6.0 & 7.2 & 8.0 & 21.2 & - & - & - & - \\
\hline Nov & 8.0 & 7.2 & 13.0 & 5.0 & 33.2 & 5.0 & 10.0 & 9.0 & 24.0 & - & - & - & - \\
\hline Dec & 12.1 & 9.6 & 11.0 & - & 36.6 & - & 8.7 & 7.7 & 16.4 & 8.0 & 3.0 & 7.2 & 18.2 \\
\hline Jan & 13.5 & 12.7 & 15.0 & 4.0 & 45.2 & 7.6 & 12.1 & 14.0 & 33.7 & 29.0 & 14.0 & 5.0 & 48.0 \\
\hline Feb & 34.2 & 13.6 & 13.0 & 9.0 & 69.8 & 9.0 & 24.0 & 25.0 & 58.0 & 79.1 & 45.0 & 39.0 & 163.1 \\
\hline Mar & 40.9 & 20.1 & 27.0 & 9.0 & 97.0 & 12.2 & 31.0 & 32.0 & 75.2 & 118 & 69.0 & 37.0 & 224.9 \\
\hline Apr & 76.0 & 41.6 & 39.0 & 16.4 & 173.0 & 27.0 & 14.0 & 13.0 & 54.0 & 273 & 77.0 & 100.0 & 450.0 \\
\hline May & - & - & - & - & - & - & - & - & - & 108 & 28.0 & 85.0 & 221.0 \\
\hline Jun & - & - & - & - & - & - & - & - & - & - & - & - & - \\
\hline July & - & - & - & - & - & - & - & - & - & - & - & - & - \\
\hline Aug. & - & - & - & - & - & - & - & - & - & - & - & - & - \\
\hline Total & 188.4 & 108.9 & 127.0 & 43.0 & 474.7 & 49.1 & 124.7 & 112.0 & 285.8 & 616.0 & 236.0 & 273.0 & 1125.2 \\
\hline Mean & 13.7 & 9.1 & 10.6 & 3.6 & 39.0 & 4.1 & 10.4 & 9.3 & 21.6 & 51.3 & 19.7 & 22.8 & 93.8 \\
\hline
\end{tabular}

Data in Table (4) indicated that, M. cantiana, $S$. putris and $T$. pisana snails were recorded on lettuce while cabbage and clover was free from $T$. pisana snails infestation during 2015-2016 growing season. Data in table (4) showed that, the highest population of S. putris per $1 \mathrm{~m}^{2}$ was detected on lettuce with range between 9.5 snails in December to 17.1 snails $/ \mathrm{m}^{2}$ in November with 94.6 snails 
$/ \mathrm{m}^{2}$ total number, followed by T. pisana 4.0 snails $/ \mathrm{m}^{2}$ in October to 20.1snails $/ \mathrm{m}^{2}$ in April with 78.5 snails $/ \mathrm{m}^{2}$ total number and $M$. cantiana was the least ranged between 3.0 snails $/ \mathrm{m}^{2}$ in December and 16.0 snails $/ \mathrm{m}^{2}$ in April with 58.7 snails total number. On the other hand $M$. cantiana, found on cabbage with range of $12.0 \mathrm{snail} / \mathrm{m}^{2}$ in December to 23.0 snails $/ \mathrm{m}^{2}$ in October and April followed by $S$. putris 9.0 snails $/ \mathrm{m}^{2}$ in September to 24.0 snails $/ \mathrm{m}^{2}$ in March with total population of 148.5 and 116.2 snails $/ \mathrm{m}^{2}$ for $M$. cantiana and $S$. putris respectively, while $T$. pisana snails was absent. On Egyptian clover, the highest population density of $M$. cantiana snails were recorded with range of 12.0 snails $/ \mathrm{m}^{2}$ in December and $215.1 \mathrm{snails} / \mathrm{m}^{2}$ in April followed by C. acuta 9.0snails $/ \mathrm{m}^{2}$ in December and 96.0 snails $/ \mathrm{m}^{2}$ in April and $S$. putris was the lowest 11.3 snails in December to 75.5 snails $/ \mathrm{m}^{2}$ in April while the total population density was 463.3, 241.0 and 182.3 individuals $/ \mathrm{m}^{2}$, for M. cantiana, $C$. acuta and $S$. patris respectively.

In the second growing season 2016-2017, results in table (5) showed that the previous snail species, M. cantiana, S. putris, T. pisana and C. acuta were recorded on lettuce. The population values revealed that highest population density of $M$. cantiana per $\mathrm{m}^{2}$ was detected on lettuce with range of 4.0 snails $/ \mathrm{m}^{2}$ to 78.1 in December and April, respectively with 193.7 total number was followed by $S$. putris 6.0 to 31.0 snails $/ \mathrm{m}^{2}$ in October and February, respectively with 153.0 snails $/ \mathrm{m}^{2}$ total number while $T$. pisana was 5.0 snails $/ \mathrm{m}^{2}$ to 43.0 snails $/ \mathrm{m}^{2}$ in October and April, respectively with 121.9 snails $/ \mathrm{m}^{2}$ total number. On the other hand, C. acuta was the least 6.2 to 15.0 in December and March, respectively with total number 57.5 snails $/ \mathrm{m}^{2}$. On cabbage, $M$. cantiana snails were found at range of 5.0 snails $/ \mathrm{m}^{2}$ in September to 41.0 snails $/ \mathrm{m}^{2}$ in March followed by C. acuta was in range 3.0 snails $/ \mathrm{m}^{2}$ in September to 29.0 snails $/ \mathrm{m}^{2}$ in March, while $S$. putris which in range 2.0 snails $/ \mathrm{m}^{2}$ in April to 19.0 snails $/ \mathrm{m}^{2}$ in May. The total number for the three species was 126.9, 102.9 and 61.3 snails $/ \mathrm{m}^{2}$ for M. cantiana, C.acuta and S.putris, respectively. Concerning field crops, the highest population density of $M$. cantiana snails were recorded on Egyptian clover with range of 21.0 to 360.0 snails/ $\mathrm{m}^{2}$ in December and April, respectively, followed by $S$. putris snails which at range 9.0 to 75.0 in December and May, respectively, while C. acuta snails were the lowest in occurrence 9.0 to 36.0 snails $/ \mathrm{m}^{2}$ in January and May, respectively, total population as 248.0, 211.0 and 117.0 individuals $/ \mathrm{m}^{2}$ for M. cantiana, $S$. putris and C.acuta, respectively.

Table 4. population dynamics of snail species on different crops at Salait village ,Quallen district during 2015-2016 season.

\begin{tabular}{|c|c|c|c|c|c|c|c|c|c|c|c|c|c|}
\hline \multirow{3}{*}{ Months } & \multicolumn{13}{|c|}{ Average number of snail species on different crops /m2 } \\
\hline & \multicolumn{5}{|c|}{ Lettuce } & \multicolumn{4}{|c|}{$\begin{array}{c}\text { Cabbage } \\
\end{array}$} & \multicolumn{4}{|c|}{ Egyptian clover } \\
\hline & $\mathbf{M}$ & $\mathbf{S}$ & $\mathbf{T}$ & $\mathbf{C}$ & Total & $\mathbf{M}$ & $\mathbf{S}$ & $\mathbf{T}$ & Total & $\mathbf{M}$ & $\mathbf{S}$ & $\mathbf{C}$ & Total \\
\hline Sep. & - & - & - & - & - & 19.0 & 9.0 & - & 28.0 & - & - & - & - \\
\hline Oct. & 7.3 & 13.0 & 4.0 & - & 29.3 & 23.0 & 11.0 & - & 34.0 & - & - & - & - \\
\hline Nov. & 5.0 & 17.1 & 12.0 & - & 34.1 & 19.7 & 15.0 & - & 34.7 & - & - & - & - \\
\hline Dec. & 3.0 & 9.5 & 10.0 & -- & 22.5 & 12.0 & 11.1 & - & 23.1 & 12.0 & 11.3 & 9.0 & 32.3 \\
\hline Jan. & 4.4 & 14.5 & 8.6 & - & 27.5 & 15.7 & 13.0 & - & 23.7 & 23.0 & 18.0 & 15.0 & 56.0 \\
\hline Feb. & 10.0 & 11.6 & 6.3 & - & 27.9 & 17.1 & 17.2 & - & 34.3 & 64.0 & 16.0 & 19.0 & 99.0 \\
\hline Mar. & 13.016 & 13.9 & 12.5 & -- & 39.4 & 19.0 & 24.0 & - & 43.0 & 115.8 & 25.8 & 27.0 & 186.0 \\
\hline Apr. & .0 & 15.6 & 20.1 & - & 51.1 & 23.0 & 15.9 & - & 38.9 & 215.1 & 75.5 & 96.0 & 386.1 \\
\hline May & - & - & - & & - & - & - & - & - & 33.4 & 36.2 & 75.0 & 144.6 \\
\hline Jun. & - & - & - & & - & - & - & - & - & - & - & - & - \\
\hline Jul. & - & - & - & & - & - & - & - & - & - & - & - & - \\
\hline Aug. & - & - & - & & - & - & - & - & - & - & - & - & - \\
\hline Total & 58.7 & 94.6 & 78.5 & - & 231.8 & 148.5 & 116.2 & - & 246.7 & 463.3 & 182.3 & 241.0 & 886.6 \\
\hline Mean & 4.9 & 7.9 & 6.5 & - & 19.3 & 12.4 & 9.7 & - & 22.1 & 38.1 & 15.2 & 20.1 & 73.8 \\
\hline
\end{tabular}

M.:Monacha cantiana C.: Cochlecilla acuta T.: Theba pisana S.:Succinea. putris

Table 5. population dynamics of snail species on different crops at Salait village, Qullen district during 2016-2017 season.

\begin{tabular}{|c|c|c|c|c|c|c|c|c|c|c|c|c|c|}
\hline \multirow{3}{*}{ Months } & \multicolumn{13}{|c|}{ Average numbers of snail species on different crops /m2 } \\
\hline & \multicolumn{5}{|c|}{ Lettuce } & \multicolumn{4}{|c|}{ Cabbage } & \multicolumn{4}{|c|}{ Egyptian clover } \\
\hline & $\mathbf{M}$ & $\mathbf{S}$ & $\mathbf{T}$ & $\mathbf{C}$ & Total & $\mathbf{M}$ & $\mathbf{S}$ & $\mathbf{C}$ & Total & $\mathbf{M}$ & $\mathbf{S}$ & $\mathbf{C}$ & Total \\
\hline Sep & - & - & - & - & - & 5.0 & 4.0 & 3.0 & 12.0 & - & - & - & - \\
\hline Oct & 11.0 & 6.0 & 5.0 & 8.0 & 26.0 & 8.0 & 3.0 & 6.0 & 17.0 & - & - & - & - \\
\hline Nov & 7.0 & 11.0 & 7.1 & 11.0 & 30.1 & 9.0 & 5.0 & 7.0 & 21.0 & - & - & - & - \\
\hline Dec & 4.0 & 23.0 & 10.2 & 6.2 & 41.2 & 7.0 & - & 7.9 & 14.9 & 21.0 & 9.0 & 11.0 & 41.0 \\
\hline Jan & 13.0 & 25.0 & 12.0 & 7.3 & 58.0 & 12.0 & 6.1 & 12.0 & 30.1 & 26.0 & 15.0 & 9.0 & 50.0 \\
\hline Feb & 28.0 & 31.0 & 13.6 & 10.0 & 82.0 & 24.0 & 8.0 & 22.0 & 54.0 & 91.0 & 53.0 & 13.0 & 157.0 \\
\hline Mar & 52.6 & 26.0 & 31.0 & 15.0 & 121.6 & 41.0 & 10.2 & 29.0 & 80.2 & 125.0 & 46.0 & 20.0 & 19.1 \\
\hline Apr & 78.1 & 30.0 & 43.0 & - & 166.0 & 20.9 & 19.0 & 16.0 & 55.9 & 360.0 & 75.0 & 28.0 & 463.0 \\
\hline May & - & - & - & -- & - & - & - & - & - & 24.6 & 22.0 & 36.0 & 82.6- \\
\hline Jun & - & - & - & - & - & - & - & - & - & - & - & - & - \\
\hline July & - & - & - & - & - & - & - & - & - & - & - & - & - \\
\hline $\mathrm{Ag}$ & - & - & - & & - & - & - & - & - & - & - & - & - \\
\hline Total & 193.7 & 153.0 & 121.9 & 57.5 & 475.6 & 126.9 & 61.3 & 102.9 & 291.6 & 248.0 & 211.0 & 117.0 & 804.6 \\
\hline Mean & 16.1 & 12.8 & 10.2 & 4.8 & 39.6 & 10.6 & 5.1 & 8.6 & 24.3 & 20.7 & 17.6 & 9.75 & 75.0 \\
\hline
\end{tabular}

M.:Monacha cantiana C.: Cochlecilla acuta T.: Theba pisana S.:Succinea. putris 
The results showed that the snails $M$. cantiana and $S$. putris were recorded in all examined crops, lettuce, cabbage and egyptian clover on the two localities. This conclusion was confirm by Maha and Awad (2008) who stated that Succinea putris and S. elgans are the most dominant species at Dumyat Governorate especially in field and on vegetable crops. These species of snails chiefly inhabit the rich places with damp soil as crops and orchards. They prefer areas covered with crops or the grassy ground (Baker and Hawke, 1990; Drake and Arias, 1995).

Estimation of damage caused by certain land snails to Egyptian clover:

Data in table (6) indicated that infestation of Egyptian clover plants with different levels of $M$. cantiana which reduced the fresh weight of variable values of reduction. At 10 snails levels, damage level were $57.1,62.7$ and $55.6 \%$ at first, second and third cutting, respectively . These values of damage was gradually increased with increased of infestation level to reach 73.2, 79.7 and 73.6 $\%$ for 25 snail level at first, second and third cutting , respectively . Average reduction was 58.5, 57.4, 64.5 and $75.5 \%$ at $10,15,20$ and 25 snails/ plant level of infestation during the three cutting. Data in table ( 7 ) showed the reduction caused by different levels of $S$. putris snails at 10 snails level, \%reduction in shoot weight were $61.4,67.7$ and $60 \%$ at first, second and third cutting respectively . When the level increased to 25 snail $/ 30$ plant, reduction in shoot weight reached to $63.1,85.3$ and $89 \%$ at first, second and third cutting respectively. From these results, \%reduction which caused by all levels of infestation by two snail species were changed from cutting to another, it increased in first cut in any level of infestation where average respective reduction values caused by all levels of infestation at the first, second and third cutting were 62.5, 62.8 and $66.7 \%$ for $M$. cantiana and $64.1,74$ and $76.7 \%$ for S. putris. The percentage of weight reduction of Egyptian clover plants were higher in third cutting compared to the other two cuttings. Therefore, it could be concluded that different levels of infestation of M. cantiana and S.putris resulted damage to Egyptian clover. The general means of reduction in plants weight were 47, 52, 54 and 60.7 and 87.4, $98.6,100$ and $109 \mathrm{gm} / 30$ plants of $M$. cantiana and $S$. putris, respectively when caged plants infested by $10,15,20$ and 25 snails $/ 30$ plants .

Table 6. Reduction of weight in clover plants caused by different infestation levels of $M$. cantiana snails under field conditions during 2017 season.

\begin{tabular}{|c|c|c|c|c|c|c|c|c|c|c|c|c|c|}
\hline \multirow[b]{2}{*}{$\begin{array}{l}\text { Level of } \\
\text { infestation }\end{array}$} & \multirow[b]{2}{*}{$\begin{array}{l}\vec{E} \\
\frac{50}{20} \\
\vec{E}\end{array}$} & \multicolumn{3}{|c|}{ First cut } & \multicolumn{2}{|c|}{ Second cut } & \multicolumn{4}{|c|}{ Third reduction } & \multicolumn{2}{|r|}{ Average } & L.S.D \\
\hline & & 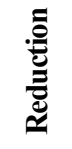 & ๑゚ & $\begin{array}{l}\vec{E} \\
\vec{E} \\
\vec{E}\end{array}$ & 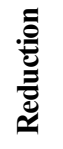 & ○゚ & 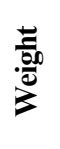 & 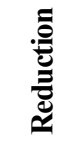 & ○゚ & E & 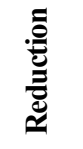 & ○゚ & $\stackrel{\leftrightarrow}{\varrho}$ \\
\hline 10 snails & 48 & 64 & 57.1 & 22 & 37 & 62.7 & 32 & 40 & 55.6 & 34 & 47 & 58.5 & 12.7 \\
\hline 15 snails & 41 & 71 & 63.4 & 24 & 35 & 39.3 & 22 & 50 & 69.4 & 29 & 52 & 57.4 & 4.9 \\
\hline 20 snails & 39 & 73 & 56.1 & 18 & 41 & 69.5 & 23 & 49 & 68 & 26.7 & 54 & 64.5 & 9.1 \\
\hline 25 snails & 30 & 82 & 73.2 & 12 & 47 & 79.7 & 19 & 53 & 73.6 & 20.3 & 60.7 & 75.5 & 8.4 \\
\hline Control & 112 & & & 59 & & & 72 & & & & & & \\
\hline Mean & & 72.5 & 62.5 & & 40 & 62.8 & & 48 & 66.7 & & & & \\
\hline
\end{tabular}

Table 7. reduction of weight in clover plants caused by different infestation levels of S. putris snails under field conditions during 2017 season.

\begin{tabular}{|c|c|c|c|c|c|c|c|c|c|c|c|c|c|}
\hline \multirow[b]{2}{*}{$\begin{array}{l}\text { Level of } \\
\text { infestation }\end{array}$} & \multicolumn{2}{|c|}{ First cut } & \multicolumn{3}{|c|}{ Second cut } & \multicolumn{3}{|c|}{ Third cut } & \multicolumn{3}{|c|}{ Average } & \multicolumn{2}{|c|}{ L.S.D. } \\
\hline & $\frac{\vec{E}}{\overrightarrow{000}}$ & • & 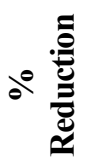 & 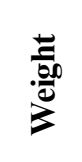 & 氖 & ๑๋ & 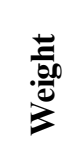 & 氖 & 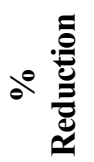 & 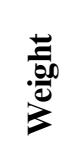 & • & 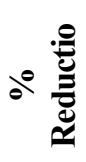 & $\stackrel{n}{0}$ \\
\hline 10 snails & 64 & 86 & 61.4 & 48.5 & 104.4 & 67.7 & 50.2 & 74.8 & 60 & 54.2 & 87.4 & 63 & 10.1 \\
\hline 15 snails & 36.6 & 103.4 & 74 & 50.6 & 99.4 & 66.3 & 32 & 93 & 74.4 & 39.7 & 98.6 & 71.6 & 12.3 \\
\hline 20 snail & 59 & 81 & 58 & 35 & 115 & 76.7 & 21 & 104 & 83.2 & 38.3 & 100 & 72.6 & 9.6 \\
\hline 25 snails & 51.6 & 88.4 & 63.1 & 22 & 128 & 85.3 & 14 & 111 & 89 & 29.2 & 109 & 79.1 & 8.1 \\
\hline Control & 140 & & & 158 & & & 125 & & & & & & \\
\hline Mean & & 89.7 & 64.1 & & 109.4 & 74 & & 96 & 76.7 & & & & \\
\hline
\end{tabular}

The land snails causing great damage to Egyptian clover at different growth stages as a result of the mucous and the particular structure of the mouth parts which enabling scratching and crushing (El-okda, 1980 and Sharshir et al., 1996). Zidan et al.,(2005) reported that the mean reduction caused by M.cartusiana in frish weight of shoots for three cutting of egyptian clover were 38.22, 33.59, $35.12 \%$ and the general mean loss was $35.65 \%$.

\section{REFERENCES}

AbdEl-Aal, S. M. (2001): Studies on certain land snails at Sharkia Governorate. M. Sc. Thesis, Fac. Agric. Zagazig. Univ., 137pp.

Arafa, A. A. (1997): Studies on some land molluscs at Sharkia Governorate. M. Sc. Thesis, Fac. Agic. Al-Azhar Univ.137pp. 
Baker, G. H. and Hawke, B. G. (1990): Life history and population dynamics of Theba pisana (Mollusca : Helicidae) in a cereal- pasture rotation. J. Appl. Ecol., 27: 16-29.

Baur, B. and Baur, A. (1993): Climatic warning due to thermal radiation from an urban as possible cause for the local extension af land snails. J. Appl. Ecol., 30: 333-340.

Drake, P. and Arias, A. M.(1995): Distribution and production of three hydrobia species (Gastropoda: Hydrobüdae ) in a shallow coastal logoon in the Bay of Cadiz, Spain. J. Moll. Stud., 61: 185-196.

El Deeb ,H.I ;.Ghamry. E. M. .; El-Hawash. N.( 1996): Relative abundance of some land snails in certain Governorate of Egypt. J.Mansoura Uni.21 (8) :2922-2933

El- Deeb, H. I.; Wilson, M. and Eshra, E. H. (1999): Ecological studies on certain land snails infesting some economic crops at Behera Governorate, Egypt. Second Int. Conf. of Pest Control, Mansoura, Egypt, Sept., 1999; 19-27.

El-Masry, S. A. (1997): Studies on the control of some land snail infesting certain fruit trees. Ph.D. Thesis, Fac. Agric. Zagazig. Univ. 150pp.

El- Okda, M. M. K. ( 1980): Land snails of economic importance on vegetable crops at Alexandria and neighboring region. J. Agric. Res. Rev., 58 (1): 79-85.

Ghamry , E.M., El-Deeb ,H.I. and Kokab.A. (1993) : Ecological and morphological studies of certain land snails at Sharkia Governorate . J. Appl. Sci. 8 (1): 213-225 .

Godan , D. (1983) :Pest slugs and snails ,Biology and control , Fedral biological Res .center of Agric and forest Konigin lusesrabe 19 D-400 Berlin : (113),(110)p.

Hegab, A. M.; Ghamry E. M; El-Masry, S. A. and Hassan, A. I. (1999): Ecological studies on certain land snails in some localities at Sharkia Governorate. Zagazig J. Agric. Res. 26 (3B): 787- 795
Ismail, Sh. A. (1997): Ecology, biology and control of certain terrestrial snails infesting some vegetables and field crops in Sharkia Governorate. Ph.D. Thesis. Fac. Agric. Zagazig Univ. 128pp.

Ismail, Sh. A. A.; Shetala, S. Z. S.; Arafa, A. I. and AbdElAtty, S. F. (2011): Incidence and seasonal fluctuation of certain land gastropod species associated with some crops and weeds at Sharkia Governorate. J. Plant Prot. And Path., Mansoura Univ., vol. 2 (12): 1103-1110.

Kassab ,A. and H. Daoud :(1964) Notes on biology and control of land snails in K. S. A ,.Zagazig J.Agri.Res.Vol.25 No (2):321-32.

Maha, F. M. and Awad, M. H. M. (2008): Population density of certain land snail and slug species and their damage to some fields and vegetable crops. Egypt.J. Agric. Res., 86 (5): 1763-1772.

Mahrous, M.E ,.Ibrahim M.H. and Abd-Elaal E.M. (2002) :Control of certain land snails under field conditions in Sharkia Governorate. Egyptian J. of Agric. Res. 29:1041-1045.

Samy, M. A., El-Fakharany, S. K. M. and Hendawy, A. S. (2015): Population fluctuation and host preference of land snail, Monacha spp. and its control of biocides compared with neomyl. J. Agric. Res., 93 (1) (A).

Sharshir, F. A.; Okka, M. A. and Hellal, R. M. Y. (1996): Non-target soil organisms and predacious mites associated with the land snail Monacha cantiana, (Muller) in Kafr El-Sheikh. Egypt. J. Agric. Res. Tanta Univ. 22 (3): 407-417.

Zedan, H.A.; M.M. Mortada and M.H. Awad (2005): Survey, damage and losses caused by land snails on certain crops at Dakahlia, Sharkia and Damietta Governorates. Egypt J. Agric., 83(2): 669-677.

$$
\begin{aligned}
& \text { حصر وتذبذب التعداد وتقدير الضرر للقواقع الأرضيه السائدة على بعض الخضراوات ومحصول البرسيم المصري في } \\
& \text { منطقتين بمحافظة كفر الثي }
\end{aligned}
$$

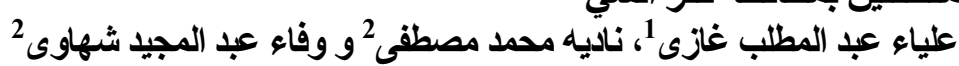

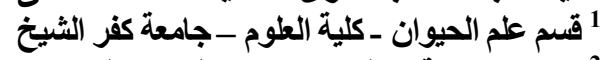

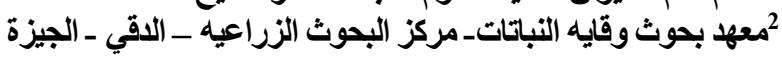

